International Journal of Multi Disipline Science (IJ-MDS)

e-ISSN: 2615-1707 DOI: http://dx.doi.org/10.26737/ij-mds.v1i1.421

This work is licensed under

a Creative Commons Attribution-NonCommercial 4.0 International License.

\title{
Disaster Relief as Indonesia Soft Power Diplomacy Case of Cyclone Pam in Vanuatu
}

\author{
Vrameswari Omega Wati ${ }^{1}$, Deffi Ayu Puspito Sari ${ }^{2}$, Sobar Sutisna ${ }^{3}$ \\ Parahyangan University ${ }^{1}$, Bakrie University ${ }^{2}$, Indonesia Defense University ${ }^{3}$ \\ vrameswariomega@ unpar.ac.id ${ }^{1}$, deffi.sari@bakrie.ac.id ${ }^{2}$, gpsutisna@gmail.com
}

\begin{tabular}{l}
\hline Keywords: \\
disaster relief, emergency \\
response decision making \\
process, melanesia, soft \\
power diplomacy
\end{tabular}

Keywords :

\begin{abstract}
Natural disasters are part of non-traditional threats that must be faced by the countries in the world. To handle this issue, the international community should improve their relations through cooperation. On March 14, 2015, Vanuatu, suffered Cyclone Pam which resulted in casualties and damage in the region. On behalf of humanity, Indonesia, as a country with great attention to disaster and who has the same of Melanesia brotherhood provide disaster relief to Vanuatu. The method used is qualitative. This paper attempts to answer how the process of providing disaster relief by Indonesia to Vanuatu and how disaster relief can be seen as a form of Indonesia's soft power diplomacy to Vanuatu. Data was obtained through in-depth interviews and literature study. The results showed the process of disaster relief is carried out in accordance with the three stages in the Emergency Decision Making Process which are assessing the situation and needs; determining goal and assistance; and implementing of response plans. Disaster relief is also a kind of Indonesia soft power diplomacy to Vanuatu to show a sense of humanity, to enhance friendship, and to maintain the integrity of the Republic of Indonesia sovereignty. After the disaster relief given by Indonesia government, relations between Indonesia and Vanuatu are starting to show shades of improvement. Cyclone Pam that happened in Vanuatu can be seen as a catalyst to improve the chances of good relations between Indonesia and Vanuatu and building cooperation in disaster management.
\end{abstract}

\section{INTRODUCTION}

The complexity of the interstate relations has generated interdependence among international actors, particularly countries (Keohane \& Nye, 2012). This is also supported by a constellation of the multipolar international system so as for encouraging countries around the world to enhance international cooperation, both bilateral and multilateral (Karns \& Mingst, 2010). International cooperation is formed by international life covering various areas such as ideology, political, 
economic, social, environmental, cultural, defense and security which led to various needs of each state entity (Perwita \& Yani, 2005). The emergence of security threats which has an increasingly broad spectrum also become an encouragement for countries to strengthen their relations. Countries should deal with not only traditional but also non-traditional threats that threaten human security, such as natural disaster.

Currently, disaster can be a common security issue and humanitarian missions can go beyond the state sovereignty (Maarif, Penanggulangan Bencana Sebagai Diplomasi Soft Power Indonesia, 2013). The widespread of disaster impacts may be one reason why this issue becomes the attention of the international community. Tsunami in Aceh in 2004 is an example of how the international community shows solidarity to Indonesia. As part of the international community, Indonesia, not only become the beneficiary of the assistance but also has a role in contributing to addressing the disaster impact in other countries (Maarif, Pikiran dan Gagasan Penanggulangan Bencana di Indonesia, 2012). It is in accordance with the Indonesia's foreign policy which is free and active.

As a country located in the Pacific Ring of Fire and surrounded by three tectonic plates causes Indonesia as a disaster-prone area, therefore, the efforts to reduce disaster risk continue to be done. These have appreciated as Global Champion for Disaster Risk Reduction in 2008 by the United Nations ( United Nations Office for Disaster Risk Reduction, 2011). It proves that the Indonesia's efforts and experiences in disaster management receive recognition in the international level so that it can be an asset for government in conducting diplomacy. In March, 2015, Vanuatu was hit by Cyclone Pam. According to United Nations Office for the Coordination of Humanitarian Affairs report, the cyclone has destroyed a 70\% of life in Vanuatu and 24 people dead ( (UN OCHA, 2015), (BNPB, 2015)). On behalf of humanity due to the impact of the destructive Cyclone Pam and solidarity as a country that has the same ethnicity of Melanesia, Indonesia send disaster relief to Vanuatu.

Disaster relief provided by Indonesia to Vanuatu is interesting to be studied, especially from the soft power perspective. Indonesia not only has the vision to become a world-class center of excellence in disaster management but also to strengthen bilateral relations. Indonesia has had cooperation with Vanuatu in various fields, such as politics, economics, education, agriculture, and social culture. But, that various cooperation still does not close the possibility of the emergence of a challenge for Indonesia. This challenge is particularly related to the improvement of political relations with Vanuatu. The head of the government substitution in Vanuatu which happens quite often have an impact on foreign policy to Indonesia (RI, 2013).

Diplomatic relations between Indonesia and Vanuatu can be considered important and strategic as one of the implementation of Indonesia's look east policy. Geographically, Vanuatu is located in the south of Pacific Ocean and east of Australia and has a background of disaster-prone and same ethnicity of Melanesia (BNPB, 2015). In addition, the position of Vanuatu which has an important role in the Melanesian Spearhead Group (MSG), an intergovernmental organization in the South Pacific region, can facilitate Indonesia in establishing a positive relation with other member countries of the MSG (Kementerian Luar Negeri Republik Indonesia, 2015). According to Bandoro (Bandoro, 2014), at the beginning, Indonesia and the South Pacific relation is not part of Indonesia's foreign policy priority. However, the current diplomatic relations more viewed from the perspective of a political rather than economic. In this regard, Indonesia requires international diplomacy not only to preserve the sovereignty and integrity but also to promote prosperity and a more active role in international relations to obtain a positive image with the use of soft power (Bandoro, 2014). Therefore, as a country that plays an active role in international relations as well as disaster management through humanitarian aid, the study will attempt to analyze how the process of disaster relief provided by Indonesia and how it can be seen as soft power diplomacy to Vanuatu. 


\section{A. Why is South Pacific Important to Indonesia?}

To analyze about the Indonesia's disaster relief to Vanuatu, it is important to understand the importance of the South Pacific for Indonesia. It attempts to describe a comprehensive overview that the bilateral relations of a country cannot be separated from the area where the country is located. Vanuatu is a country located in the South Pacific region so it is necessary to know its policy and Indonesia's foreign relations in the region. According to the study of BPPK ${ }^{1}$, the South Pacific is covering all the countries located in the Southern Pacific Ocean, or commonly referred to Oceania, which is located in the east of Indonesia, especially small countries, and did not include Australia and New Zealand in this grouping (RI, 2013).

Using a concentric circle geostrategic approach to setting region priorities in the implementation of Indonesia's foreign policy, the South Pacific region is an area bordered directly to Indonesia and also the nearest neighbor after the Southeast Asia (RI, 2013). Therefore, it is right to assign this region to become one of Indonesia's foreign policy priorities. In general, countries in the South Pacific region consist of 16 countries, but socio-culturally, the region has three sub-regions, namely Melanesia, Polynesia, and Micronesia. Melanesian sub-region includes the country of Papua New Guinea, Solomon Islands, Vanuatu, New Caledonia, Fiji, and five provinces in eastern Indonesia. These five provinces include Papua, West Papua, Maluku, North Maluku and East Nusa Tenggara. The Melanesian population has physical characteristics, such as, a dark-skinned in accordance with the meaning of the term Melanesia is derived from Melas which means dark (RI, 2013).

Indonesia views the South Pacific region as relative peace region (Bandoro, 2014). However, most countries in the South Pacific region have unstable governance and domestic political problems. Thus, international community; including Indonesia view this region is vulnerable to political instability (Bandoro, 2014). Seeing such conditions, Indonesia still opens cooperation with countries in the South Pacific. In the last ten years, Indonesia used soft power approach through cooperation to enhance the relations in the South Pacific (Relations, 28 September 2015).

On the other hand, it does not mean that the relations between Indonesia in the South Pacific region always go hand in hand. The possibility of disruption towards political stability and security of Indonesia still remains (Bandoro, 2014). According to Bandoro, "the aspirations of certain areas in Indonesia to secede may invite the sympathy of some countries in the South Pacific region" (Bandoro, 2014). Therefore, the South Pacific region has a strategic value, especially related to Indonesia's efforts to maintain the sovereignty so it is important to continue to preserve its relations with countries in the South Pacific region (RI, 2013).

\section{B. Bilateral Relations between Indonesia and Vanuatu}

Diplomatic relations between Indonesia and Vanuatu was officially opened in 1995 (RI, 2013). History records that the important milestone of bilateral relations between Indonesia and Vanuatu is the signing of the Joint Communique on the Occasion of the Visit of the Foreign Minister of the Republic of Vanuatu to Indonesia in 2004 (RI, 2013). The joint communique is a reaffirmation of the commitment of both countries to develop relations of friendship and cooperation based on mutual respect, non-intervention in relation to each other, equality, and the advantages of each other (Dokumen Resmi Joint Communique Kemlu RI, 2004). But, bilateral relations between both countries have its own challenges particularly, their political relations.

According to the BPPK Ministry of Foreign Affairs, "In the year 2013, the Vanuatu government headed by Prime Minister Moana Carcasses is implementing policies that lead to dynamics relations between Indonesia and Vanuatu" (RI, 2013). Prime Minister Moana Carcasses seem to have special attention to the issue of Papuan independence which is reflected in his speech at the UN Human

\footnotetext{
${ }^{1}$ BPPK is Badan Pengkajian dan Pengembangan Kebijakan
} 
Rights Council session in Geneva on March 4, 2014( (Kementerian Luar Negeri Republik Indonesia, 2015), (Pemerintah Vanuatu, 4 Maret 2014)). Based on his statement, Carcasses seeks to UN Secretary General and the countries that attended the session may give attention also to the challenges of human rights against indigenous Melanesians in Papua since 1969 which he said was chronic (Pemerintah Vanuatu, 4 Maret 2014). His statement can be analyzed that Mr. Carcasses emphasized that the Papuans are ethnic Melanesians, allied also with the people of Vanuatu. Carcasses felt it was important to bring this issue because a fraternal bond of Melanesia.

Based on his speech, Mr. Moana Carcasses clearly takes his position in voicing the issue of Papua to the international forum. Moana Carcasses voiced that the Papuan people deserve freedom as equal citizens, and questioned the quality of governance in Indonesia (Pemerintah Vanuatu, 4 Maret 2014). Later in the same year, Prime Minister Moana Carcasses was replaced by Joe Natuman leadership. Similarly, Joe Natuman also has a great attention to the problems of Indonesian sovereignty. It is proved through a statement he made in the UN General Assembly in New York on September 29, 2014 (Kementerian Luar Negeri Republik Indonesia, 2015). Joe Natuman's statement described his support for the self-determination of the Papuan people (Pemerintah Vanuatu, 2014). Through his speech, Joe Natuman tried to voice towards UN and other nations in efforts to uphold democracy to contribute to the future of Papuan self-determination.

Facing a campaign conducted by the Government of Vanuatu, the Indonesian government prefers to take a softer approach through the diplomatic track. This paper does not specifically discuss the Papua issue, but try to describe how the situation of the relations between Indonesia and Vanuatu and how Indonesia's efforts to improve the relations using soft power. The measures taken by Indonesia do not disregard Vanuatu but rather attempts to strengthen their relations through cooperation ( (Farissi, 4 September 2015), (Relations, 28 September 2015)). The disaster that occurred in Vanuatu in March 2015 may open opportunity for Indonesia to strengthen the diplomatic relations which have disrupted by the statement of the Prime Minister of Vanuatu in 2014 and to improve the image of Indonesia.

\section{RESEARCH QUESTION}

This paper has research questions as follows,

1. How is the process of disaster relief provided by Indonesia to Vanuatu?

2. How can disaster relief be analyzed as soft power diplomacy Indonesia to Vanuatu?

\section{FRAMEWORK}

Problem identification in figure 1 begins by describing the problems faced by both countries. Vanuatu is a country that supports self-determination for Papuan peoples, which are part of the Indonesia sovereignty ( (Pemerintah Vanuatu, 2014), (RI, 2013)). This support is delivered through a speech by Prime Minister Moana Carcasses at a session of UN Human Rights Council in Geneva on March 4, 2014, and also the Prime Minister Joe Natuman at $69^{\text {th }}$ UN General Assembly in New York in 2014 ( (Kementerian Luar Negeri Republik Indonesia, 2015)- (Pemerintah Vanuatu, 2014)). This becomes a threat to the national integrity and the image of Indonesia in the world because the domestic issue rose at the international level. Therefore, it is important for Indonesia to enhance friendship with Vanuatu. However, in March 2015, Vanuatu was hit by Cyclone Pam disaster that so the government makes policies to accept international assistance.

The Indonesian experiences in disaster management and seeing the condition of Vanuatu who needs assistance to address the Cyclone Pam gives opportunities for Indonesia to strengthen friendly relations with Vanuatu and to maintain the sovereignty. Indonesia also wants to show that they have a Melanesian bond with Vanuatu through disaster relief. This paper observed that the assistance is part of the use of soft power by Indonesia through disaster diplomacy. This effort is analyzed as an attempt to obtain a positive image of Indonesia in the world as well as an effort to counter the Vanuatu's support for self-determination to Papuan people. 


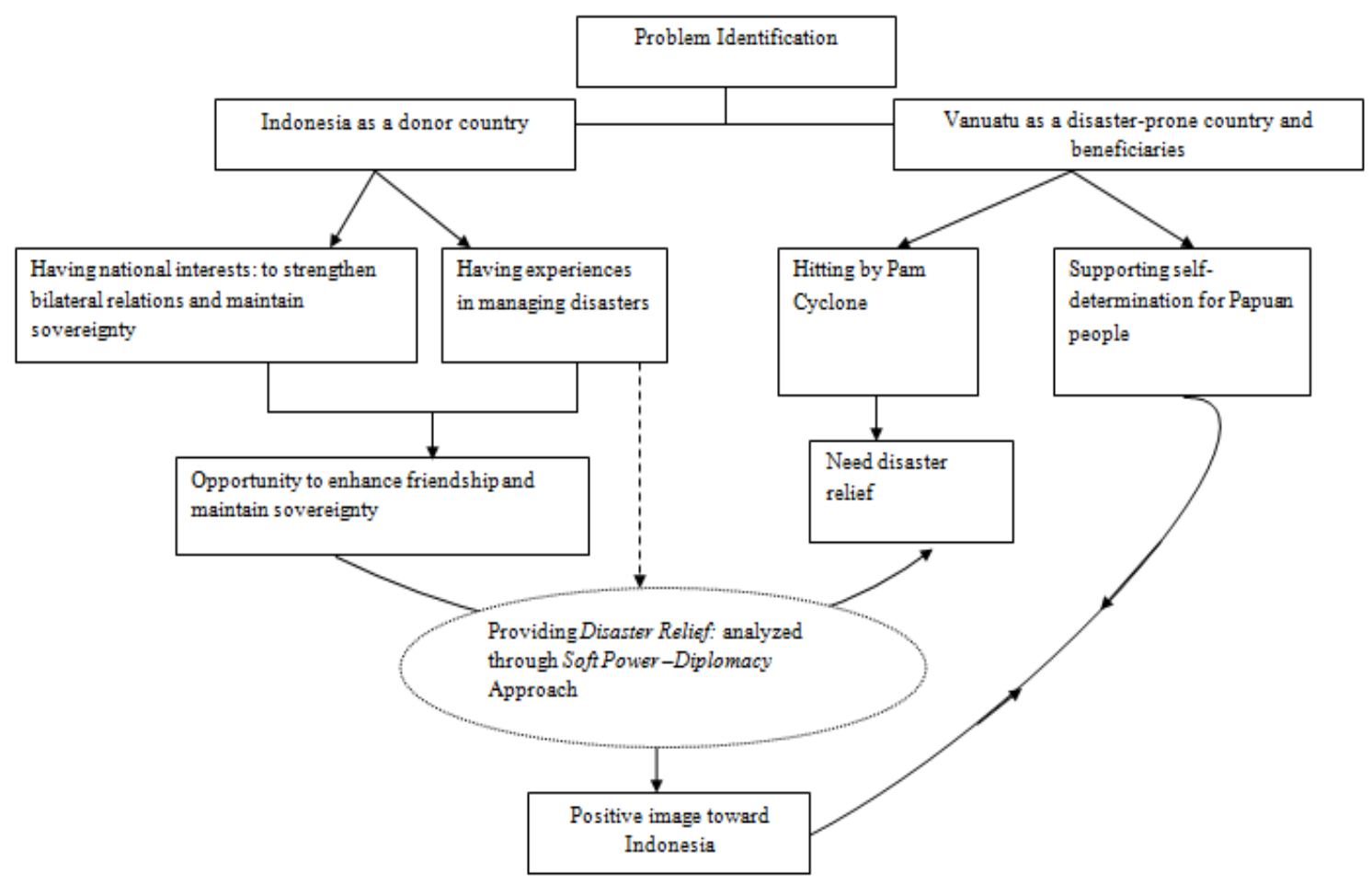

Fig.1 Problem Identification

\section{THEORY: DEFINING DISASTER RELIEF, EMERGENCY RESPONSE DECISION MAKING PROCESS, DIPLOMACY AND SOFT POWER}

This research used three concepts and one theory to answer the research question. The concepts are disaster relief, emergency response decision making process, and diplomacy. The theory is soft power.

Disaster relief or other terms called emergency management/humanitarian aid refers to the process of responding to disaster situations, providing humanitarian assistance to the people and communities who suffered from the disaster (International Federation of Red Cross and Red Crescent Societies, 2000). Disaster relief is goods or services available to individuals and communities who suffered because of disasters (New World Encyclopedia, 2013). Another definition according to the United States Legal, disaster relief is rapid assistance to relieve the suffering of disaster victims which aims to meet the urgent needs of them (United States Legal, 2015). Based on the definitions, we can conclude that disaster relief is a humanitarian response to alleviate the suffering of disaster victims by providing goods or services.

Furthermore, emergency response plan consists of three phases as described below.

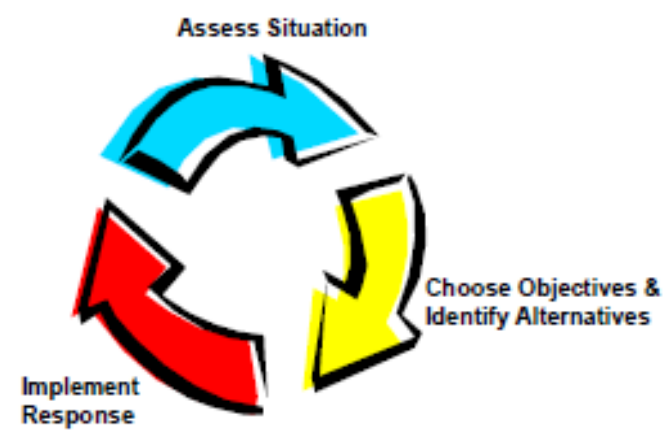


Fig 2. Emergency Response Decision Making Process

Source: IFRC (International Federation of Red Cross and Red Crescent Societies, 2000)

In Figure 2, we can see that Emergency Response Decision Making Process according to IFRC encompasses of three stages which are assessing situation and needs of the disaster victims, determining the objectives and identifying the assistance that will be provided, and implementing response based on the assessment and the objectives (International Federation of Red Cross and Red Crescent Societies, 2000). This describes how the decision ideally is made in an emergency situation.

According to Coppolla, when a country in the emergency situation does not have the ability to overcome the effects of the disaster, the country may request assistance from other countries (Coppola, 2007). For those countries that already have experience of dealing with mega-disaster, these countries have the opportunity to assist other countries in coping with disaster risk (Coppola, 2007). What the state do to help other countries that affected by the disaster can be called a diplomacy.

Diplomacy is a tool that countries do to establish international relations, both bilateral and multilateral (Frankel, 1971). Other definitions state that diplomacy is simply defined as wisdom, skill or proficiency in dealing with others (Young, 2008). The other view according to Geoffrey Berridge (2002:4), in Young (2008), suggests that 'diplomacy consists of communication between officials designed to promote the foreign policy either through formal agreements or tacit adjustment' (Young, 2008). From the aforementioned definitions, we can conclude that diplomacy is a method or art owned by people who have the capability to negotiate in conducting international relations among countries to conduct foreign policy in order to achieve its national interests.

Diplomacy is also included as an effort by countries to achieve national interests using soft power approach. Power according to Joseph Nye is difficult to define and measure. He stated that the definition of power will change according to the context. Power according to Nye refers to the ability to influence the actions of other parties to get the desired results (Joseph S. Nye, 2004). Some ways can be carried out to influence others by forcing them through threats; or can be pushed with a payment; or can attract and co-opt them to do what the influencer want. In a global information age, the use of soft power is more influential rather than hard power (Chong, 2007).

According to Joseph Nye, "soft power is the ability to get what you want through attraction rather than coercion or payments. It arises the attractiveness of a country's culture, political ideals, and policies" (Joseph S. Nye, 2004). Soft power is the derived from the culture, domestic policy (political value), and foreign policy. Talking about the context of national interests, Joseph Nye has an opinion that "winning the peace is more difficult than winning the war and soft power is essential to win the peace" (Joseph S. Nye, 2004).

The correlation between disaster and international cooperation as an implementation of soft power that is undertaken by a country, Ilan Kelman in Hutabarat found a diplomatic process as a bridge to achieve cooperation in the field of disaster management ( (Hutabarat, 2013), (Kelman, 2012)). Ilan Kelman viewed this new study as disaster diplomacy (Kelman, 2012). Disasters can be a catalyst in the process of diplomacy. That is, disaster may open opportunities to reduce conflict and disaster risk in the framework of cooperation (Kelman, 2012).

Based on the description of the theory and concepts that have been elaborated, the experience and capability of disaster management are a soft power that Indonesia owned and could be used to help Vanuatu to overcome the effects of Cyclone Pam through disaster relief. Furthermore, the analysis will be examined on how disaster relief can be understood as Indonesia soft power diplomacy to Vanuatu. 


\section{METHOD}

This research used qualitative research methods. The purpose of qualitative research is to discover and understand the meaning of a phenomenon and then the results are described in a narrative or textual (Creswell, 1998). To obtain the necessary data, this research takes the primary and secondary data sources. Primary data obtained through interviews technique using snowball sampling method. The informants were chosen specifically and qualified in about the research and directly involved in the delivery of disaster relief in Vanuatu. Meanwhile, secondary data sources are from the official situation report issued by the Vanuatu government, UN OCHA, IFRC, BNPB reports, documents, and official publication of the relevant institutions. In addition, secondary data was also collected through newspaper articles, books, and other academic writings. This research used data collection techniques through in-depth interviews and literature study. Meanwhile, data analysis used Miles and Huberman models, including data collection, data reduction, data display, and conclusion. This research has limitations in obtaining data because it cannot interview directly the Vanuatu government. This is due to limited access to the data. This research was conducted in 2016 after Cyclone Pam occurred in Vanuatu.

\section{RESULT AND DISCUSSION}

\section{A. Process of Disaster Relief Provided Indonesia to Vanuatu}

The process of disaster relief by Indonesia to Vanuatu will be discussed using the concept of Emergency Decision Making Process, which carried by IFRC which consists of three stages: assessing the situation and needs; determining goals and identifying forms of assistance; and implementing of response plans (International Federation of Red Cross and Red Crescent Societies, 2000).

First stage is assessing situation and needs. Before determining the goals and identifying assistance, Indonesia government should assess the situation after Cyclone Pam hit Vanuatu and identify the needs of the affected people. But, there was no a special team from Indonesia who directly assessed situation and needs of the victim to the field. The information was obtained by Indonesia government through the assessment process was assisted by the Indonesia Embassy in Canberra, Australia and Suva, Fiji, Ministry of Health of the Republic of Indonesia, the Australian government, WFP, Indonesia Red Cross, and UN OCHA.

Basically, the assessment which conducted by Indonesia government already described the top priority needs of the disaster victim that is required by IFRC. But, the Indonesia government has yet to assess in some specific sectors such as psychological and social aspects yet. Based on the result of the assessment in Vanuatu, the Indonesia government has set that food and nonfood sectors become the priority of disaster relief. Indonesia government also faced the obstacles in assessing the situation and needs. The obstacles come from the geographic factor and limited access and resources. Vanuatu is an archipelagic country. When the Cyclone stroke the country, the infrastructure was paralyzed and the transportation was limited to reach the affected area. It influenced to the assessment process so the information about situation and needs which was obtained by Indonesia government was not much details.

The second stage is determining goals and identifying assistance. Indonesia has humanitarian mission to alleviate the suffering of the affected people and to rehabilitate the damaged infrastructure after the destructive Cyclone happened. Based on the result of situation and needs assessment in affected area, Indonesia determined to provide food and non-food sectors as priority that will be given. Vanuatu needed a help to meet the basic needs of instant foods, nutrient-added foods, tents, blankets and also to restore existing infrastructure The objective is only delivering logistics assistance to those in need and financial assistance to the Vanuatu government. This mission is in line with the needs of Vanuatu to reduce fatalities, to meet basic needs, and to rehabilitate and reconstruct infrastructure. Furthermore, the goals and the assistance provided by Indonesia to Vanuatu meet the concept of 
disaster relief according the New World Encyclopedia and United States Legal, which is to alleviate the suffering of the victims, to meet the immediate needs of disaster victims and to rebuild the communities ( (New World Encyclopedia, 2013), (United States Legal, 2015)). The total assistance provided by Indonesia to Vanuatu worth as 2 million US dollars.

The last stage is implementing the response plan. The assistance was symbolically given by the Ambassador of the Republic of Indonesia to Australia, H.E. Najib Riphat Kesoemato to the Minister for Climate Change and Natural Disasters, James Bule at the National Disaster Management Office, Vanuatu. A brief meeting was held between the Chief of Delegate of Indonesia Embassy and the Vanuatu government, including Minister of Foreign Affairs of Vanuatu Sato Kilman and Prime Minister Hon Joe Yhakowaie Natuman. In the meeting, Prime Minister of Vanuatu, Joe Natuman expressed his gratefulness from Vanuatu people for the aid from Indonesia ( (BNPB, 2015), (BNPB, 2015), (The Jakarta Post, 2015)). Indonesian Ambassador to Australia and Vanuatu also emphasized that the humanitarian mission and aid provided by Indonesia is to express that Vanuatu is Indonesia's close friend. There are some obstacles that faced by Indonesia team in implementing the response plan such as administration and financial related problem, technical problem, and field situation related to political-matter.

\section{B. Disaster Relief as Indonesia Soft Power-Diplomacy to Vanuatu in Addressing Cyclone Pam}

Why disaster relief is referred to as diplomacy? It can be understood based on the basic concept of diplomacy as it concerns bilateral relations between the two countries. Indonesia disaster relief provided to Vanuatu is an effort of doing international relations as stated by Frankel (Frankel, 1971). Indonesia is able to make its experiences in disaster management as capital to manage the relations with other countries, it is in line with the definition of diplomacy expressed by Collins, 1990; Shultz, 2003, in Young, 2008 (Young, 2008). Disaster relief provided by Indonesia may also be understood as the implementation of Indonesia's look east policy. Indonesia has a special attention to countries in South Pacific, including Vanuatu. Look East Policy is a guide for Indonesia in managing the relations with Vanuatu.

The interesting thing in this study is how diplomacy can be understood as an attempt to achieve the national interest. Disaster relief provided by Indonesia has main reason to show solidarity and humanity. This was stated by Indonesia Minister of Foreign Affairs, in joy and sorrow that Vanuatu is a friend of Indonesia. However, this paper analyzes other considerations why Indonesia provides relief to Vanuatu. The consideration is based on the national interests of Indonesia includes two things, enhance friendship with Vanuatu within the framework of the Melanesian culture and maintaining the sovereignty of the Indonesia's homeland.

Meanwhile, in some provinces in the eastern region of Indonesia such as Papua, West Papua, Maluku, North Maluku and East Nusa Tenggara is part of the Melanesian sub-region, as well as Vanuatu. They have physical characteristics similar to the people of Vanuatu. Therefore, the Indonesian government wants to assert that the country is part of Melanesia. The assistance provided by Indonesia to Vanuatu also is based on considerations to strengthen friendship as a fellow nation that has the same ethnic. Disaster relief provided by Indonesia has a desire to give an understanding to the people and government of Vanuatu that Indonesia has always been a companion in any situation and work together.

On the other hand, Indonesia's bilateral relations with Vanuatu has its own dynamics. There are times when relations between the two countries have a roller coaster situation. This is due to the domestic political struggle in the government of Vanuatu. The political instability in Vanuatu government system leads to a challenge for Indonesia. The successions of leaders often happen in Vanuatu affect its foreign policy to Indonesia. Moreover, Vanuatu also has special attention towards Papua issue that showed through international forum, such as in UN meeting. 
The Vanuatu Prime Minister's speech that stated about human rights issues and their support to selfdetermination of the Papuans is a big problem for Indonesia because it touches Indonesia sovereignty. In addition, it also affects the image of Indonesia in international level for bringing domestic issues to the international arena. Policies that Indonesia applies to Vanuatu certainly cannot be separated from the corridor of Indonesia's national interests to maintain its integrity.

Indonesia choose not to use effort through coercion or payment as expressed by Chong (Chong, 2007) in facing the dynamics of bilateral relations with Vanuatu, particularly in response to a campaign on self-determination for the people of Papua by the former Prime Minister of Vanuatu. The approach used is to remain embraced Vanuatu as a friendly country (Farissi, 4 September 2015). The assistance provided by Indonesia can be analyzed as an effort to reach Vanuatu society. Indonesia wants to show as a country that has a sense of great sympathy and concern towards his brother, Melanesians in Vanuatu who are victims of Cyclone Pam. Indonesia's approach can be understood as the use of soft power as described by Joseph Nye (Joseph S. Nye, 2004). Then, the question that arises is whether the disaster relief is part of the attraction to obtain Indonesia's interest. Reviewing the significance of the South Pacific for Indonesia, bilateral relations between Indonesia with Vanuatu, and also the experiences of Indonesia in disaster management, the disaster relief can be analyzed as an attraction to achieve Indonesia's interest as stated in Nye (Joseph S. Nye, 2004). As explanation before, there are three interests that Indonesia desire to achieve; showing its solidarity and humanity; strengthening bilateral relations; and maintaining its integrity.

According to Nye, there are three sources of soft power, namely culture, political values and foreign policy (Joseph S. Nye, 2004). First, when we observed in disaster relief given by Indonesia is also bringing cultural elements. Indonesia always stresses that most of its region have the same culture of Melanesia as Vanuatu. The approach taken is rooted in the same Melanesian ethnic between Indonesia and Vanuatu.

Second, the source of soft power is political values. Indonesia is trying to show that they are a democratic country that upholds human rights. The disaster relief that was given to the society is a great concern to help to alleviate the suffering of Cyclone Pam victims. Indonesia wants to show its solidarity and humanity to the people of Vanuatu. In this term, Indonesia want to implicitly convey the message that they concerned with society outside the country just as they care for people in their own sovereign territory. Indonesia was already several times to give relief not only to Vanuatu but also to some countries, such as Japan, Myanmar and the Philippines. It can be analyzed as an attempt to counter the voice delivered by Mr. Carcasses in a speech at the UN Human Rights Council in Geneva.

Third, Indonesia has 'look east policy' that wants to be consistently implemented. The assistance provided by Indonesia to Vanuatu is one example of implementation of this policy. This policy provides guidance to Indonesia to improve its relations with countries in the South Pacific, including Vanuatu. Disaster relief can be understood as the ability of Indonesia through the framework of humanitarian aid as stated by Joseph Nye to achieve the objective. Disaster relief in dealing with the impact of Cyclone Pam has objectives to show a sense of humanity, to promote friendship as a nation that has the same Melanesia culture and to maintain the integrity of the Republic of Indonesia. This assistance can also be understood as a form of soft power diplomacy Indonesia to obtain a positive image. Having a sense of high sympathy to the suffering country is the image that intended to be formed by Indonesia.

Relation between Indonesia and Vanuatu at that time also began to show shades of improvement. Team from Indonesia was well welcomed by officials at the Ministry of Foreign Affairs of Vanuatu, including greeted by Prime Minister Joe Natuman. Meanwhile, Vanuatu Foreign Minister came to Indonesia when the Asia Africa Conference held in 2015. This shows a fairly good interaction. Foreign Minister of Vanuatu, Sato Kilman, conveyed his gratitude to the assistance given by the Indonesia Government. Sato Kilman also expressed his desire to open embassy in Jakarta and Indonesia also ask to open an embassy in Port Villa ( (Farissi, 4 September 2015), (Jakarta Globe, 
2015), (Kompas, 2015)). However, the intention to build the Embassy of Vanuatu in Jakarta cannot be realized until now because there is no official request from the government of Vanuatu and it will take a long process. In addition, Mr. Natuman has a great attention to the issue of Papua and has not time to make a visit to Indonesia. Vanuatu also frequent changes their leadership and does not have one voice in determining its foreign policy toward Indonesia so it takes a long-term efforts and continuous to be done to maintain friendly relations with Vanuatu. However, the gesture conveyed by Minister of Vanuatu at the time of Asia Africa Conference has a special meaning for Indonesia. There is a better approach process between Vanuatu and Indonesia (Farissi, 4 September 2015). Therefore, Cyclone Pam can be seen as a catalyst which, according to Ilan Kelman may open opportunities to promote good relations between Indonesia and Vanuatu and also more concrete cooperation particularly in disaster management.

\section{CONCLUSION}

This study has conclusion as follows:

1. The process of disaster relief by Indonesia to Vanuatu to overcome the effects of Cyclone Pam is in line with the stages in Emergency Response Decision Making Process. They are assessing the situation and needs; determining goal and assistance; and implementing of response plans. Based on the assessment process, the Indonesia government determines food and non food sectors as a priority assistance of the disaster victims. The disaster relief objectives are to reduce the suffering of the affected people and to rehabilitate the damaged infrastructure. The assistance was symbolically given by the Ambassador of the Republic of Indonesia to Australia. Indonesia was well welcomed by government of Vanuatu.

2. The provision of disaster relief to Vanuatu is part of Indonesia's effort to conduct diplomacy. In this term, Indonesia use soft power in doing bilateral relations with Vanuatu. It can be analyzed from the three main sources of soft power; culture, value, and foreign policy. Disaster relief which was provided by Indonesia to Vanuatu creates an opportunity to approach Vanuatu government for a better relations in the future especially related to the Papua issue.

\section{REFERENCE}

United Nations Office for Disaster Risk Reduction. (2011, November 18). Retrieved Desember 20, 2014, from http://www.unisdr.org/archive/23632.

Bandoro, B. (2014). Indonesia Dalam Lingkungan Strategis yang Berubah. Yogyakarta: Graha Ilmu.

BNPB. (2015, April 4). Retrieved Mei 13, 2015, from http://www.bnpb.go.id/berita/2419/misikemanusiaan-indonesia-untuk-vanuatu.

BNPB. (2015). Laporan Penugasan Operasi Kemanusiaan Tanggap Darurat Bencana Taufan Pam di Republik Vanuatu 4-10 April 2015. Jakarta: BNPB.

Chong, A. (2007). Foreign Policy in Global Information Space: Actualizing Soft Power. London: Palgrave McMillan.

Coppola, D. P. (2007). Introduction to International Disaster Management. Oxford: Elsevier.

Creswell, J. (1998). Research Design: Qualitative, Quantitative, and Mixed methods Approaches. Thousand Oaks: Sage Publications.

Dokumen Resmi Joint Communique Kemlu RI. (2004). Joint Communique On The Occasion of The Visit of The Foreign Minister of The Republic of Vanuatu, The Hon. Moana Carcasses Kalosil to Indonesia. Jakarta: Kemlu RI.

Farissi, D. B. (4 September 2015). Interview. 
Frankel, J. (1971). The Intellectual Framework of British Foreign Policy. In K. K. Morgan, Britain and West Germany: Changing Societies and the Future of Foreign Policy (pp. 81-103). London: Oxford University Press.

Hutabarat, G. E. (2013). Penerapan Soft Power Indonesia dalam Penanggulangan Bencana di Myanmar Studi Kasus Penanganan Bencana Alam Siklon Nargis. Jakarta: Universitas Pertahanan Indonesia.

International Federation of Red Cross and Red Crescent Societies. (2000). Disaster Emergency Needs Assessment. Geneva: IFRC.

Jakarta Globe. (2015). Retrieved Januari 5, 2016, from http://jakartaglobe.beritasatu.com/news/vanuatu-to-open-embassy-in-jakarta/

Joseph S. Nye, J. (2004). Soft Power: The Means to Success in World Politics. New York: Public Affairs.

Karns, M. P., \& Mingst, K. A. (2010). International Organizations: The Politics and Processes of Global Governance Second Ed. London: Lynne Rienner Publishers.

Kelman, I. (2012). Disaster Diplomacy: How Disaster Affect Peace and Conflict. Abingdon: Routledge.

Kementerian Luar Negeri Indonesia. (2010, Maret 14). Soft Power Memperkuat Formula Diplomasi. Tabloid Diplomasi, p. 4.

Kementerian Luar Negeri Republik Indonesia. (2015). Background Information Hubungan Bilateral Republik Indonesia-Vanuatu. Jakarta: Kemlu RI.

Kementerian Luar Negeri Republik Indonesia. (2015, Februari 14). Hubungan Ekonomi IndonesiaVanuatu Penting dan Strategis. Tabloid Diplomasi, pp. 16-17.

Keohane, R. O., \& Nye, J. (2012). Power and Interdependence. Boston: Longman.

Kissinger, H. (1994). Diplomacy. New York: Simon \& Schuster.

Kompas. (2015). Perkuat Kerja Sama Bilateral: RI Minta Dukungan untuk Menjadi Anggota DK $P B B$. Jakarta: Gramedia.

Maarif, S. (2012). Pikiran dan Gagasan Penanggulangan Bencana di Indonesia. Jakarta: BNPB.

Maarif, S. (2013). Penanggulangan Bencana Sebagai Diplomasi Soft Power Indonesia. In J. C. (Editor), Isu Bencana dalam Hubungan Internasional. Yogyakarta: Graha Ilmu.

New World Encyclopedia. (2013, November 10). Retrieved April 16, 2015, from http://www.newworldencyclopedia.org/entry/Disaster_relief.

Pemerintah Vanuatu. (2014). Delivering on and implementing a Transformative Post-2015 Pidato Resmi Joe Natuman dalam Sidang Majelis Umum PBB ke 64. New York: Republik Vanuatu.

Pemerintah Vanuatu. (4 Maret 2014). Pidato Resmi Moana Carcasses pada Sidang Dewan HAM PBB di Jenewa.

Perwita, A. A., \& Yani, Y. M. (2005). Pengantar Ilmu Hubungan Internasional. Bandung: Remaja Rosdakarya.

Relations, E. i.-V. (28 September 2015). Interview. 
RI, P. P. (2013). Kebijakan Luar Negeri Indonesia di Kawasan Pasifik Selatan: Menimbang Etnis Melanesia dalam Diplomasi Indonesia. Jakarta: Badan Pengkajian dan Pengembangan Kebijakan Kemlu RI.

Sinai, M. (1990). Co-operation: the CMEA Experience. In A. Groom, \& P. Taylor, Frameworks for International Co-operation . London: Pinter.

The Jakarta Post. (2015, Oktober 30). Retrieved Februari 26, 2016, from http://www.thejakartapost.com/adv/2015/10/30/in-joy-and-sorrow-vanuatu-our-friend.html

UN OCHA. (2015). Flash Appeal Emergency Response Plan for Vanuatu tropical Cyclone Pam March-June 2015. Bangkok: UN OCHA.

UN OCHA. (2015). Situation Report Vanuatu: Severe Tropical Cyclone Pam. Bangkok: OCHA Regional Office for the Pacific.

United States Legal. (2015). Retrieved April 16, 2015, from http://definitions.uslegal.com/d/disasterrelief\%20\%.

Young, J. W. (2008). Twentieth- Century Diplomacy: A Case Study British Practice 1963-1976. Cambridge: Cambridge University Press. 